\title{
Canthocamptus iaponicus (Crustacea: Copepoda: Harpacticoida), and Three New Species of the Genus from Japan
}

\author{
Teruo Ishida' and Yoshiaki Kikuchi ${ }^{2}$ \\ '372 Irifunecho, Yoichimachi, Hokkaido 046-0011, Japan \\ ${ }^{2}$ Center for Water Environment Studies, Ibaraki University. \\ Itako-machi, Ibaraki 311-2402, Japan
}

(Received 9 September 1997; Accepted 17 September 1998)

\begin{abstract}
A redescription of Canthocamptus iaponicus Brehm is given, and three new species from Japan are described: Canthocamptus kitaurensis, C. macrosetifer, and C. takkobuensis. Canthocamptus iaponicus and C. kitaurensis are close to the North American species $C$. staphylinoides and the Asian species $C$. carinatus. The other two new species are close to the Eurasian species $C$. stuphylinus and $C$. microstaphylinus. The distribution ranges of these species in Japan as well as a key are presented.

Key Words: Copepoda, Canthocamptus, freshwater fauna, Japan.
\end{abstract}

\section{Introduction}

The first species of the genus Canthocamptus recorded from Japan was $C$. iaponicus, described by Brehm (1927) from Lake Aoki in Nagano Prefecture in Honshu. Due to the inadequate original description, Tatsunori Itô attempted to collect specimens from the type locality for redescription, but his effort was not rewarded (personal communication to YK). The illustrations of supposed $C$. staphylinus from Japan in Itô and Miura (1973) apparently actually pertain to of Attheyella byblis Chang and Kim, 1992. Moreover, Ishida's (1987, 1989, 1990, 1995) records of $C$. staphylinus from various parts of Japan are also incorrect. We reexamined the specimens in Ishida's collection and discovered that the Japanese $C$. staphylinus-like species comprise four species, i. e., C. iaponicus and three new species. In this report we document the distribution ranges and provide descriptions of these four species. The description of each species was made by its first finder.

\section{Materials and Methods}

All specimens of $C$. staphylinus-like species in Ishida's collection were reexamined. Additional collection was made from waters in Yoichi-machi, Hokkaido, in the fall of 1996. Drawings and measurements were made either in glycerin before dissection, or in gum-chloral medium after dissection. High magnification objective lenses used were mainly $\times 60$ (not oil-immersion) and $\times 40$ (phase-contrast), but occasionally a differential interference apparatus at a magnification of $\times 500$ was used. Type specimens have been deposited in the Department of Zoology, National Science Museum (Tokyo) (NSMT), and the National Museum of Natural History, Smithsonian Institution (Washington D. C.) (USNM). 
Abbreviations used are as follows: B. L., body length excluding caudal setae; Al, antennule; A2, antenna; Md, mandible; P1-P6, first to sixth leg; exp1-exp3, first to third article of exopod; enpl-enp3, first to third article of endopod; $\mathrm{L} / \mathrm{W}$, ratio of length to maximum width.

\section{Taxonomic Account and Distribution}

Order Harpacticoida G. O. Sars, 1903

Family Canthocamptidae G. O. Sars, 1906

Genus Canthocamptus Westwood, 1836

Canthocamptus iaponicus Brehm, 1927

(Figs 1,2)

Synonymy: Canthocamplus staphylinus (Jurine, 1820). Ishida 1987: 79, pl. $2 \mathrm{~m}$; Ishida, 1989: 1-8 (in part, specimens from Hyogo and Nagano Prefs).

Material: 1 ㅇ and $2 \delta^{7} \sigma^{7}$ dissected on 2 slides; 12 우 우 and $1 \sigma^{7}$ undissected in $70 \%$ ethanol, USNM 284149, all from roadside ditch in Yoichi-machi, Hokkaido, 23 October, 1996. 4 우 우 and $1 \delta^{\pi}$ dissected on 2 slides, $70 \mathrm{~m}$ depth in Lake Biwa, middle Honshu, 13 April 1993, coll. A. Ohtaka; 2 ㅇ ㅇ dissected on 1 slide, pathside ditch near Fusenotame, Yohkaichi, Shiga Pref., 4 December 1995; 1 우 mounted whole on 1 slide, small irrigation pond, Saijoh, Hiroshima Pref., 16 December 1996.

Description. Female: Body cylindrical. B. L. of specimens examined 0.85-1.02 mm. Rostrum nearly obsolete. Integumental windows (nuchal organs) present on cephalothorax (Fig. 1a) and 1st free prosomite (similar to Fig. 3b). Surface of cuticle on all somites with rows of microspinules, except on integumental windows. Posterior margins of hyaline fringes of all somites finely serrated, except that of cephalothorax. First urosomal somite with row of spinules near postcrolateral margin. Genital double-somite and following two urosomites with rows of spinules near posterior margins. Anal somite with rows of spinules laterally and ventrally near posterior margin (Fig. 1c, d). Anal operculum convex, bearing 9-13 spinules. Posterodorsal hairs on each side of anus long and prominent (Fig. 1d, arrow). Caudal rami (Fig. Ic,d) long, cylindrical, and slightly divergent, $\mathrm{L} / \mathrm{W}$ about 2.7; dorsally directed seta inserted at midlength; anterior two-fifths of lateral surface of ramus with seta, setule, and 2 spinules; posterior third with seta and 2 spinules; and distal margin with 3 dorsolateral and 4 medioventral spinules. Lengths (in $\mathrm{mm}$ ) of terminal caudal setae of specimen examined (body length, $1.02 \mathrm{~mm}$ ), from lateral to medial: $0.21,0.57,0.08$. Lateral terminal caudal seta slender with hairlike tip (Fig. 1e). Seminal receptacle as in Fig. $1 \mathrm{~b}$; copulatory pore at posterior two-fifths of genital double-somite; spermatophore as in Fig. 3d, attached with colored cement.

A 1 8-segmented, number of setae and aesthetasc of each segment, from proximal to distal: $1,8,5,2+\mathrm{e}, 1,3,2$, and $7+\mathrm{e}$, aesthetasc on segment 4 reaching middle of apical segment. Exopod of A2 (Fig. 1f) 2-segmented, exp1 with seta and fine spinules on distal margin, exp2 with 3 setae. Md palp 2-segmented, proximal segment with row of spinules distally, distal segment with 1 seta at middle, 4 setae and row of 

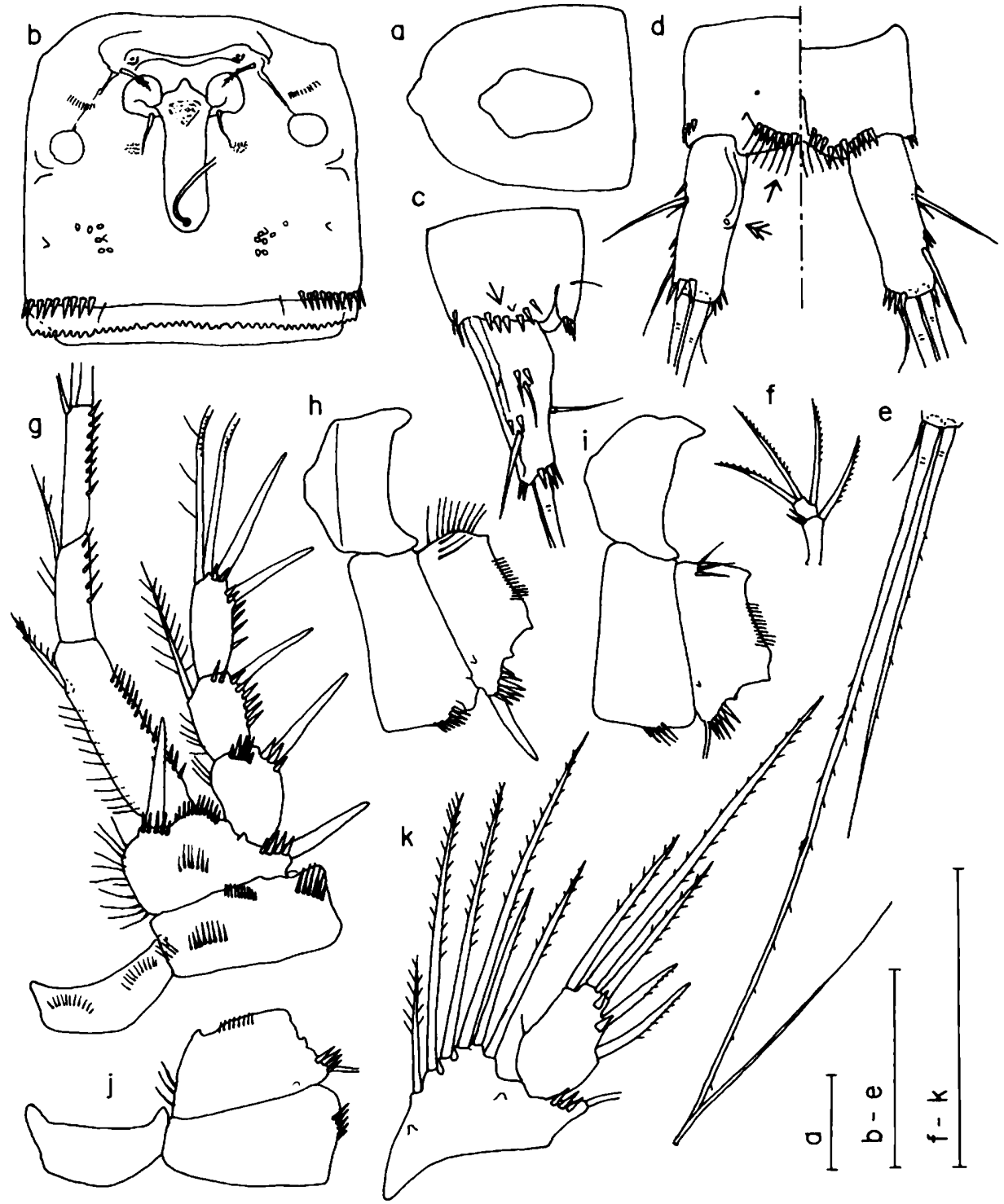

Fig. 1. Canthocamptus iaponicus, female: a, cephalothorax, dorsal; b, genital double-somite, ventral; $c$-d, anal somite and caudal ramus, lateral and dorsal/ventral; e, terminal setae of caudal ramus; $f$, cxopod of $\mathrm{A} 2 ; \mathrm{g}, \mathrm{Pl}$ and coupler, anterior; $\mathrm{h}-\mathrm{j}, \mathrm{P} 2-4$ coxa, basis and coupler, anterior; $\mathrm{k}$. P5. Scales $=100 \mu \mathrm{m}$.

spinules distally.

Setation formula of P1-4 typical for genus. P1 enpl shorter than exopod (Fig. $1 \mathrm{~g}$ ). Coupler of P1 with row of fine spinules on each side; those of P2-4 unarmed (Fig. (h-j). 


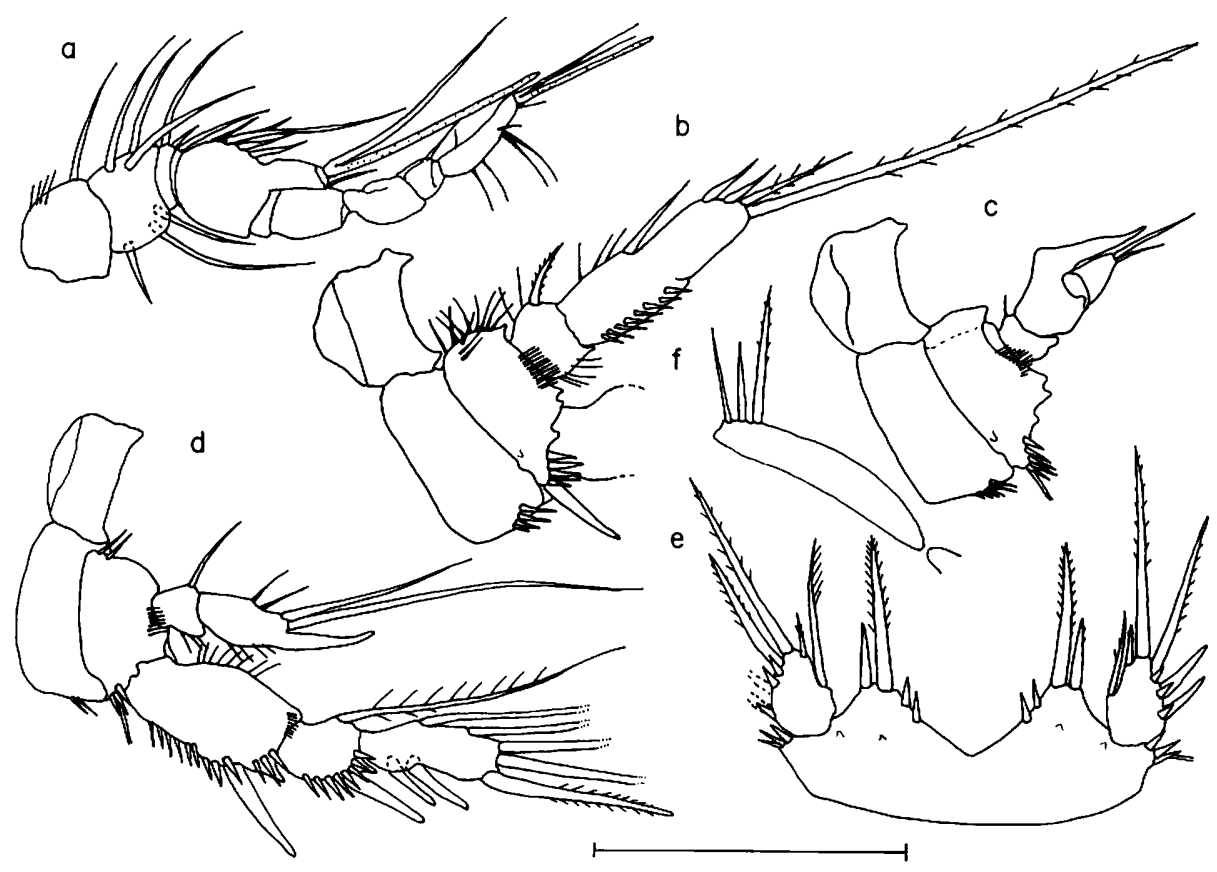

Fig. 2. Canthocamptus iaponicus, male: a, A1; b, P2 endopod and coupler, anterior; c-d, P3-4 endopod and coupler, anterior; e, P5; f, P6. Scale $=100 \mu \mathrm{m}$.

P5 (Fig. 1k) with medial expansion of baseoendopod bearing 6 spines; L/W of exopod about 1.6, bearing 5 spines and occasionally rudimentary medial setule.

P6 (Fig. la) consisting of thin plate bearing 1 plumose seta.

Male: B. L. 0.66-0.87 mm, resembling female. Anal operculum with 7-9 spinules.

A1 geniculate, 10-segmented, and armed as shown in Fig. 2a; aesthetasc on segment 5 reaching beyond tip of apical segment.

P1 as in female; endopod of P2 2-segmented and as shown in Fig. 2b; P3 enp1 (Fig. 2c) with remnant medial seta and protuberance laterally, enp2 robust with short tapering process, enp3 short with 2 setae; P4 modified as in Fig. 2d; leg 5 (Fig. 2e) with medial expansion of baseoendopod bearing 2 spines and 2 spinules, $\mathrm{L} / \mathrm{W}$ of exopod about 1.4, bearing 1 medial seta and 5 spines, medial seta of left leg much longer than that of right one; P6 as Fig. 2f.

Geographical distribution. This species has been collected from Hiroshima, Hyogo, Shiga, and Nagano Prefectures, and Hokkaido. A wide distribution in Honshu and Hokkaido is likely.

Range of habitats. The species inhabits the littoral to profundal of lakes, the middle and lower reaches of rivers and streams, and ponds and ditches. It is sympatric with C. macrosetifer and C. takkobuensis described below.

Variation. The middle and lateral terminal caudal setae are jointed at the base in some individuals.

Affinities. As Brehm (1927) pointed out, the species is close to C. slaphylinoides Pearse, 1905, found in North America. The significant diagnostic feature of $C$. 
iaponicus is the absence of spinules on the medial face of both caudal rami (versus presence of spinules at that location in C. staphylinoides). Canthocamptus carinatus Shen and Sung, 1973 resembles $C$. iaponicus closely, but it is distinguishable by the long P1 enpl, which reaches to the tip of exp3 (Tai and Song 1979).

Canthocamptus kitaurensis Kikuchi, sp. nov.

(Figs 3, 4)

Material: Holotype 우, dissected on 1 slide, NSMT-Cr 12140. Paratypes, $2 \sigma^{\nearrow} \sigma^{\pi}$ dissected on 2 slides, NSMT-Cr 12141-2; 1 우 dissected on 1 slide, NSMT-Cr 12143, all from Lake Kita-ura, Ibaraki Pref., 28 October 1987, coll. YK. Other specimens, 5 우 우 and $1 \sigma^{7}$ undissected in 70\% ethanol, USNM 261790; 3 우 우 dissected on 2 slides, all from Lake Biwa, middle Honshu, 4 December 1995; 2 우 우 and 2 б $\sigma^{7}$ dissected on 2 slides, from Zenpukuji-ike, Suginami, Tokyo, 7 April 1996.

Description. Female: Body cylindrical; B. L. of holotype and paratype $0.75 \mathrm{~mm}$ and $0.70 \mathrm{~mm}$, respectively. Other 5 specimens from Lake Biwa 0.73-0.85 mm, 2 specimens from Zenpukuji-ike 0.73 and $0.75 \mathrm{~mm}$. Rostrum nearly obsolete. Integumental windows present on cephalothorax and lst free prosomite (Fig. 3a, b). Surface of cuticule on all somites with rows of microspinules except on integumental windows. Posterior margins of hyaline fringes of all urosomites finely serrated. Genital double-somite and following two urosomites with rows of spinules near posterior margins (Fig. 3c, d). Anal somite with rows of spinules laterally and ventrally near posterior margin (Fig. 3c, e). Anal operculum convex, bearing 6-8 spinules. Posterodorsal hairs on each side of anus long and prominent (Fig. 3c). Caudal rami (Fig. 3c, e) parallel, L/W about 2; dorsally directed seta inserted at midlength; anterior two-fifths of lateral surface of ramus with seta, setule, and 2 spinules; posterior fifth with seta and 2 spinules; distal margin with 5 dorsolateral to lateral and 3 median spinules; medioventral surface of ramus with spinules at midlength. Lengths of terminal caudal setae of holotype (in $\mathrm{mm}$ ), from lateral to medial: $0.16,0.50,0.04$. Lateral terminal caudal seta slender with hairlike tip. Middle and lateral terminal caudal setae jointed at base. Seminal receptacle as shown in Fig. $3 c$, d; copulatory pore at middle of genital double-somite; spermatophore attached with colored cement.

A 1 8-segmented, setation same as that of previous species, aesthetasc on segment 4 reaching middle of 8 th segment. Exopod of A2 (Fig. 3f) 2-segmented, exp1 with seta and fine spinules on distal margin, exp2 with 3 setae. Md palp 2-segmented: proximal segment with spinule row distally; distal segment with 1 seta at middle, 4 setae and spinule row distally.

Setation formula of P1-4 typical for genus. Pl enpl shorter than exopod (Fig. $3 g$ ). Couplers of P1-2 with row of fine spinules on each side. Frontal surfaces of coxae of P1-4 ornamented with rows of microspinules (Figs $3 g-i, 4 a$ ).

P5 (Fig. 4b) with medial expansion of baseoendopod bearing 6 spines, next to rudimentary lateral spine; $\mathrm{L} / \mathrm{W}$ of exopod 1.5 , with 5 spines and medial spinules.

P6 (Fig. 3c) consisting of thin plate bearing 1 plumose seta.

Male: B.L. of 2 paratypes $0.57,0.65 \mathrm{~mm}$, resembling female. Anal operculum with 6-8 spinules.

Al geniculate, 10-segmented, and armed as shown in Fig. 4c; aesthetasc 


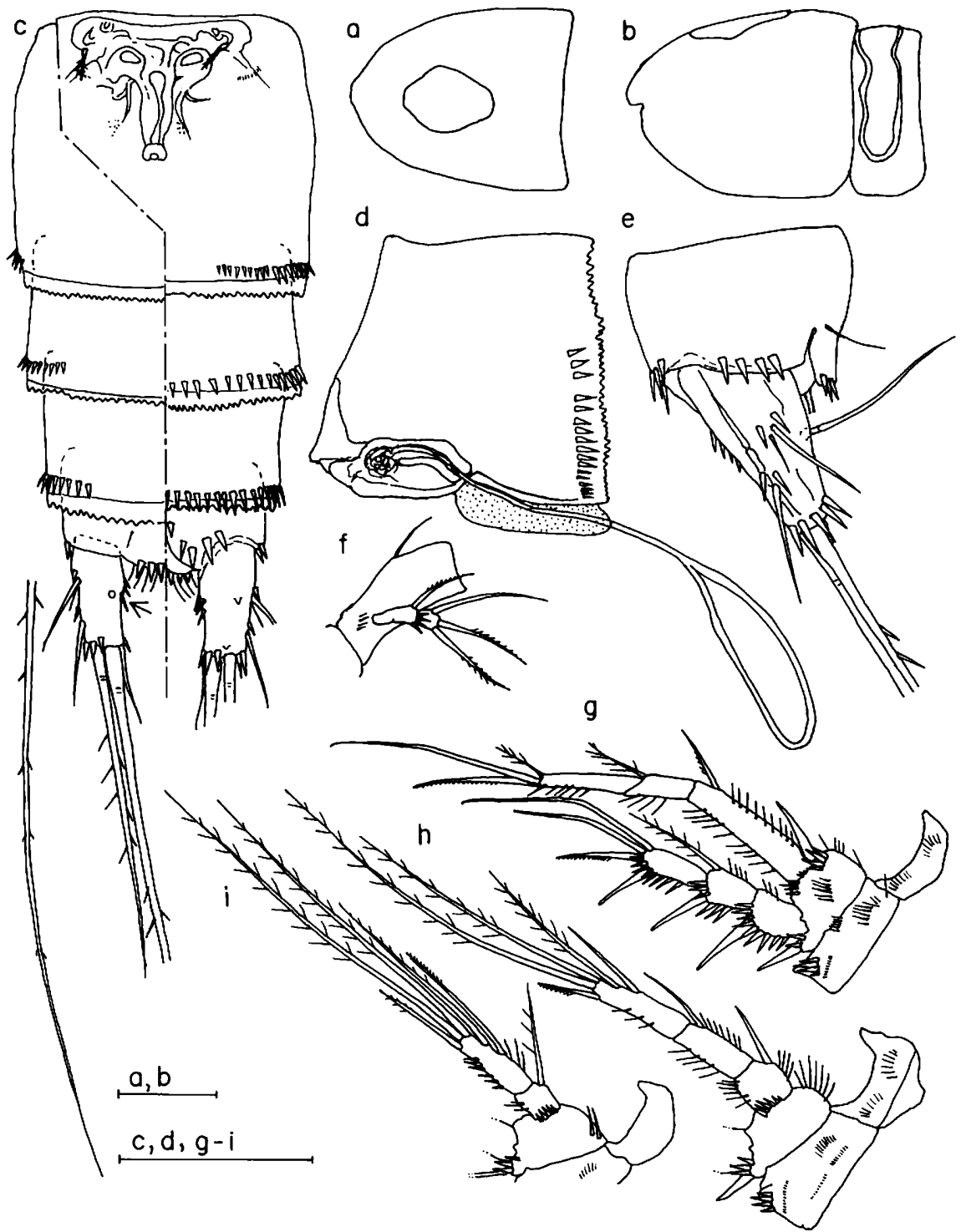

Fig. 3. Canthocamptus kitaurensis sp. nov., female, holotype: a, cephalothorax, dorsal; b, cephalosome and 1st free prosomite, lateral; c, genital double-somite and abdomen, dorsal/ ventral; d, genital double-somite with spermatophore, lateral; e, anal somite and caudal ramus, lateral; f, A2 basis and exopod; g, P1, anterior; h, P2 endopod and coupler, anterior; i, P4 endopod and coupler, anterior. Scales $=100 \mu \mathrm{m}$.

onsegment 5 reaching middle of terminal segment.

P1 as in female; endopod of P2 2-segmented and as shown in Fig. 4d; P3 enp1 (Fig. 4e) with medial seta and protuberance laterally, enp2 with short tapering 


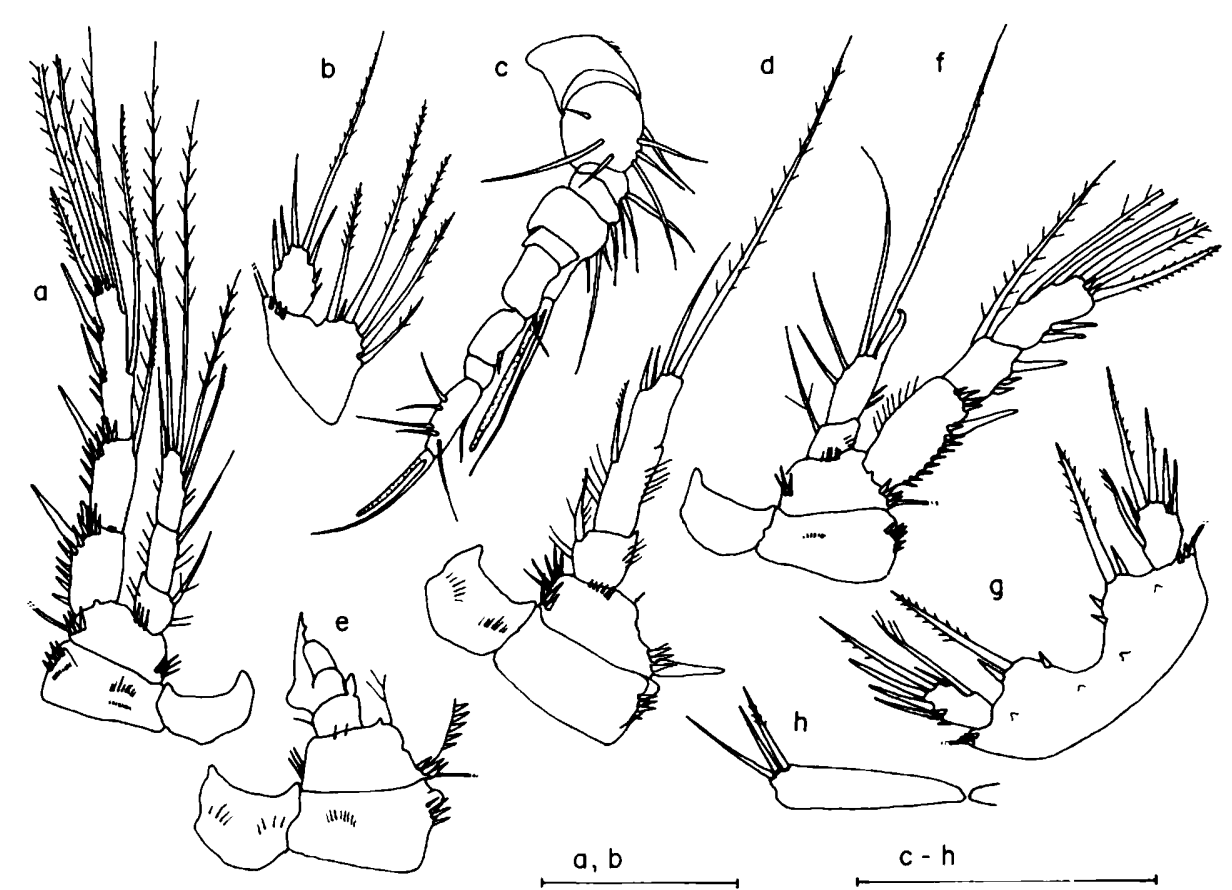

Fig. 4. Canthocamptus kitaurensis sp. nov., female, holotype: a, P3 and coupler, anterior; b, P5. Canthocamplus kitaurensis sp. nov., male, paratype: c, A2; d-f, P2-4 endopod and coupler, anterior; g, P5; h, P6. Scales $=100 \mu \mathrm{m}$.

process, enp3 short and without setae; $\mathrm{P} 4$ enp2 terminal spine modified as in Fig. 4f; P5 (Fig. 4g) with medial expansion of baseoendopod bearing 2 spines and 1 or 2 spinules, exopod with medial seta next to medial rudimentary seta, and 4 spines, medial seta of left side longer than that of right; P6 as in Fig. $4 \mathrm{~h}$.

Etymology. The species is named after the type locality, Lake Kita-ura.

Geographical distribution. At present, this species is known only from Lake Kita-ura in Ibaraki Pref., Zenpukuji-ike in Suginami, Tokyo, and Lake Biwa. Further survey is needed.

Range of habitats. The species seems to inhabit littoral zones of lakes and large ponds.

Variation. Not detected among the specimens examined, except for the number of spinules on the anal operculum.

Affinities. This species closely conforms to the original description of $C$. staphylinoides Pearse, 1905 and specimens from Alaska (NMNH 204762) reexamined by ourselves, except for the endopod of P3 of the male. The enp3 of this leg in $C$. kitaurensis is short and unarmed, while that in C. staphylinoides is long and bears 2 unequal setae, of which the lateral one is much longer. The species is also similar to C. iaponicus and C.carinatus, especially in the shape of the male P3 endopod. However, $C$. kitaurensis is quite different in the caudal rami, i. e., the medial surface of this species has spinules, while the caudal rami of $C$. iaponicus and $C$. carinatus lack spinules. 
Canthocamplus macrosetifer Ishida, sp. nov.

(Figs 5,6)

Synonymy: Canthocamptus staphylinus (Jurine, 1820). Ishida, 1987: 79, pl. 2 a-i; Ishida, 1989: 1-8 (in part, specimens from Hyogo, Fukui and Nagano Prefs.); Ishida, 1990: 40-43; Ishida, 1995: 299.

Material: Holotype 우 dissected on 1 slide, NSMT-Cr 12144. Paratypes, $2 \sigma^{7} \sigma^{7}$ dissected on 1 slide, NSMT-Cr 12145; 2 ㅇ 우 dissected on 1 slide, NSMT-Cr 12146; 25 우 우 and $10 \sigma^{7} \sigma^{7}$ undissected in 70\% ethanol, USNM 261791, all from roadside ditch in Yoichi-machi, Hokkaido, 23 October 1996. Other specimens, 5 우 우 and 1 중 dissected on 3 slides, Lake Biwa, middle Honshu, 4 December 1995; 1 우 and 1 万斤 dissected on 1 slide, pathside ditch near Fusenotame, Yohkaichi, Shiga Pref., 4 December 1995; 2 우 우 and $8 \sigma^{\pi} \sigma^{\pi}$ dissected on 3 slides, Ponkutosan Stream, Kutchan, Hokkaido, 5 October 1994; 2 우 우 and $1 \sigma^{\pi}$ dissected on 2 slides, hillside ditch in Hosomimachi, Nobeoka, Miyazaki Pref., 8 March 1989.

Description. Female: Body cylindrical; B. L. of holotype $0.82 \mathrm{~mm}$, range of 27 paratypes 0.81-1.01 mm. Rostrum nearly obsolete. Integumental windows present on cephalothorax (Fig. 5a) and 1st free prosomite (similar to Fig. 3b). Surface of cuticle on all somites with rows of microspinules except on integumental windows. Posterior edges of hyaline frills on all somites smooth. Genital double-somite and following two urosomites with rows of spinules near posterior margins. Anal somite (Fig. 5c, d) with posteroventral row of spinules on each side; distal lateral corner with blunt protuberance (arrow in Fig. 5d); anal operculum convex, bearing 9 (6-9 in paratypes) spinules; without posterodorsal rows of hairs on anus. Caudal rami (Fig. $5 \mathrm{c}, \mathrm{d})$ parallel, cylindrical, $\mathrm{L} / \mathrm{W}$ about 2.3; dorsally directed seta inserted at midlength; anterior third of lateral surface of ramus with seta and setule; posterior fourth with seta and 2 spinules; distal margin with 5 dorsolateral (double arrow in Fig. 5d) and 3 medioventral spinules. Lengths of caudal terminal setae of holotype (in $\mathrm{mm}$ ), from lateral to medial: $0.21,0.60,0.04$. Lateral terminal caudal seta robust and rod-like, 3 times longer than caudal ramus. Seminal receptacle as in Fig. 5b; copulatory pore at posterior three-sevenths of genital double-somite; spermatophore attached with colored cement.

A 1 8-segmented, setation same as that of previous species, aesthetasc on segment 4 reaching middle of 8 th segment. Exopod of A2 (Fig. 5e) 2-segmented, expl with seta and fine spinules on distal margin, exp2 with 3 setae. Md palp (Fig. 5f) 2segmented, proximal segment with spinule row distally, distal segment with 1 seta at midlength and 4 setae and spinule row distally. Other mouthparts (Fig. $5 \mathrm{~g}-\mathrm{i}$ ) as in congeners (cf. Gurney 1932; Itô and Takashio 1980).

Setation formula of P1-4 typical for genus. P1 enp1 shorter than exopod (Fig. 5j). Couplers of P1-2 with row of spinules on each side; those of P3-4 unarmed (Fig. $5 \mathrm{j}-\mathrm{m}$ ).

P5 (Fig. 5n) with medial expansion of baseoendopod bearing 6 spines, next to rudimentary lateral spine; $\mathrm{L} / \mathrm{W}$ of exopod about 1.7 , bearing 5 spines.

P6 (Fig. 5b) consisting of thin plate bearing 1 plumose seta and gonopore medially.

Male: B. L. of 12 paratypes $0.69-0.81 \mathrm{~mm}$, resembling female. Anal operculum with $5-8$ spinules.

Al geniculate, 10-segmented, and armed as in Fig. 6a; aesthetasc on segment 5 reaching middle of 10 th segment. 


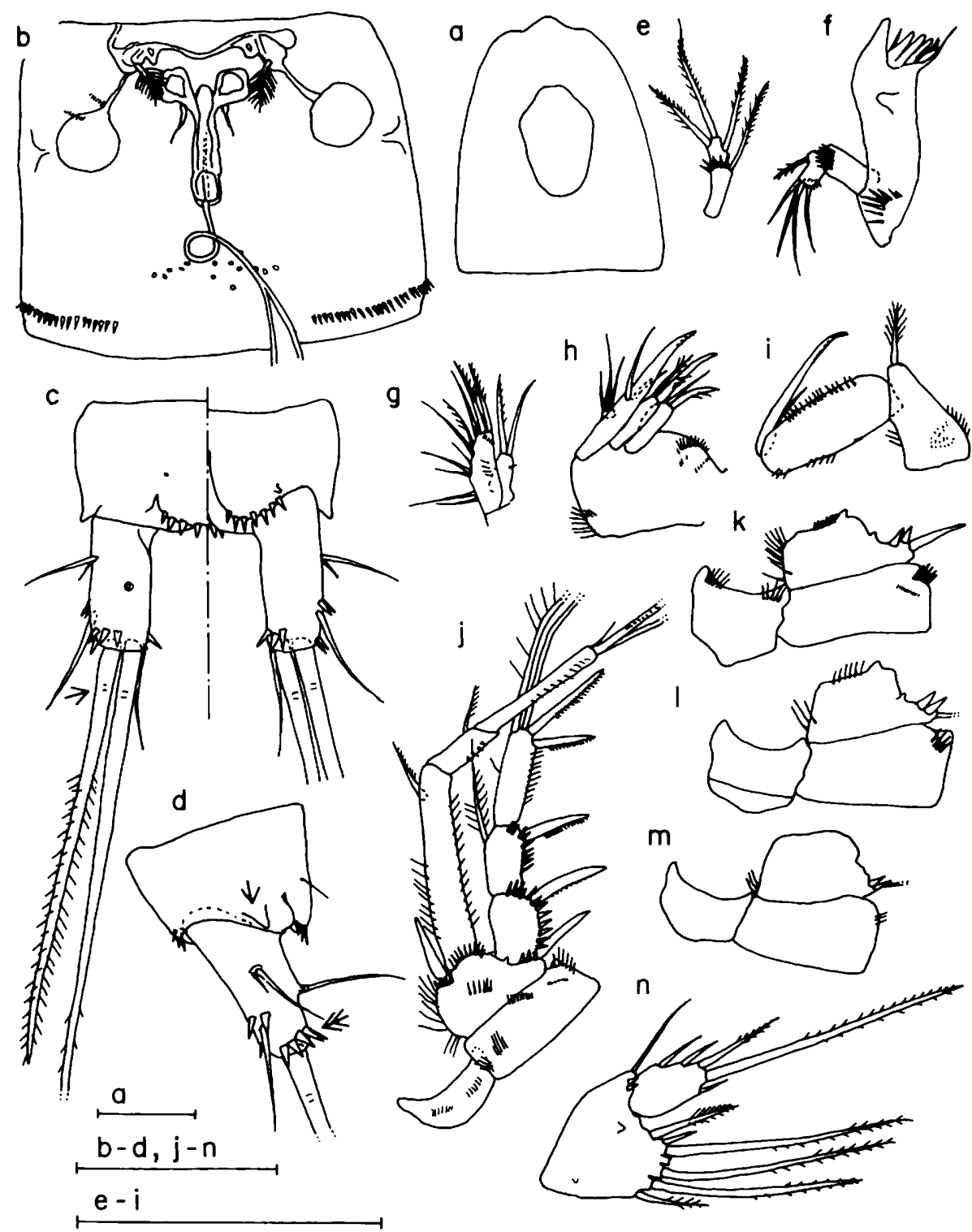

Fig. 5. Canthocamptus macrosetifer sp. nov., female, holotype: $a$, cephalothorax, dorsal; $b$, genital double-somite, ventral; c-d, anal somite and caudal ramus, dorsal/ventral and lateral; e, A2 exopod; f, Mandible; g, Maxillule; h, Maxilla; i, Maxilliped; j, Pl and coupler; k-m, P2-4 coxa, basis, and coupler, anterior; $\mathrm{n}, \mathrm{P} 5$. Scales $=100 \mu \mathrm{m}$.

$\mathrm{P} 1$ as in female; P2 endopod 2-segmented and as shown in Fig. 6b; P3 enpl with medial seta, enp2 with long medial process 3 times longer than segment 3 , short seta arising from posterior distal border, enp3 ellipsoidal with 2 short spines (Fig. 6c); P4 endopod modified as in Fig. 6d; P5 (Fig. 6e) with medial expansion of baseoendopod 


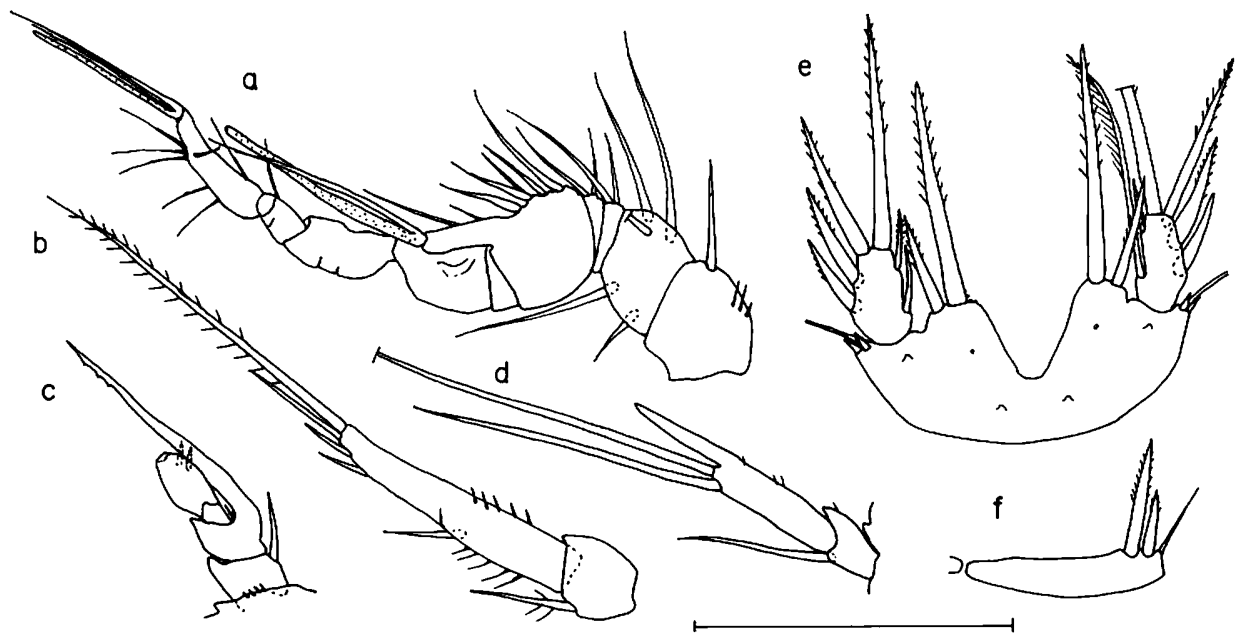

Fig. 6. Canthocamptus macrosetifer sp. nov., male, paratype: a, $\Lambda$ I; b, P2 endopod; c, P3 endopod; d, P4 endopod; e, P5; f, P6. Scale $=100 \mu \mathrm{m}$.

bearing 2 spines, L/W of exopod about 2, bearing 1 medial seta and 5 spines, medial seta on left side much longer than on right (otherwise in three of 13 males examined).

Etymology. Named for the robust appearance of the lateral terminal seta of the caudal ramus.

Geographical distribution. The species is very common in Honshu and Hokkaido. It was also found in a hillside ditch in Miyazaki Pref., Kyushu.

Range of habitats. The species commonly inhabits hillside ditches, ponds, and the middle and lower reaches of rivers and streams. It is also found in the littoral zones of oligotrophic to eutrophic lakes.

Variation. The length of the lateral terminal caudal seta varies among individuals: the observed range was 1.4-3.4 times the length of the caudal ramus.

Affinities. The new species is similar to C. staphylinus and C. microstaphylinus (Gurney 1932; Lang 1948; Borutskii 1952; Dussart 1967). However, $C$. microstaphylinus lacks the medial seta on the male P5 exopod (Gurney 1932: fig. 556; Dussart 1967: fig. 102), whereas it is present on that of C. macrosetifer. Canthocamptus staphylinus lacks the "helle Stelle" or joint (Gurney 1932; Lang 1948) on the middle and lateral terminal caudal setae, but it is present in both setae of $C$. macrosetifer (arrow in Fig. 5c). The number of spinules on the anal operculum is 8-17 $(\mathrm{N}=101$, mean $=13.1$, s. d. $=1.8$ ) in C. staphylinus (Gurney 1933), versus $6-9$ in $C$. macrosetifer. The spermatophore is a thick-walled, almost parallel-sided and distally dilated tube in C. staphylinus (Gurney 1932: fig. 529), but has a normal, flask-like form in C. macrosetifer. 
Canthocamptus takkobuensis Ishida, sp. nov.

(Figs 7, 8)

Synony my: Canthocamptus staphylinus (Jurine, 1820). Ishida, 1987: 79, pl. 2k.

Material: Holotype of dissected on 1 slide, NSMT-Cr 12147. Paratypes, 1 万 dissected on 1 slide, NSMT-Cr 12148; 2 우 우, whole mounts on 1 slide, NSMT-Cr $12149 ; 12$ 우 웅 and $3 \sigma^{7} \sigma^{7}$ undissected in 70\% ethanol, USNM 261792, all from a pond in Yoichi-machi, Hokkaido, 7 December 1996. Other specimens, 1 ㅇ and 1 万 dissected on 1 slide, from above pond, 13 April 1996; 3 우 우 and $3 \sigma^{\pi}$, whole mounts on 2 slides, Lake Takkobu-numa, Hokkaido, 11 June 1984.

Description. Female: Body cylindrical; B.L. of holotype $0.93 \mathrm{~mm}$, range of 12 paratypes $0.92-1.08 \mathrm{~mm}$. Rostrum nearly obsolete. Integumental windows present on cephalothorax (Fig. 7a), truncate posteriorly, and on 1st free prosomite similar to Fig. 3b. Surface of cuticle on all somites with rows of microspinules, except for integumental windows. Posterior edges of hyaline frills on prosomites and 1st urosomite smooth; those of genital double-somite and following two urosomites irregularly serrated. Genital double-somite and following two urosomites with rows of spinules near posterior margins. Anal somite (Fig. 7c, d) with ventral posterior row of spinules on each side; distal lateral corner with blunt protuberance; anal operculum convex, bearing 13 (11-14 in paratypes) spinules; without posterodorsal row of hairs on each side of anus. Caudal rami (Fig. 7c, d) parallel, cylindrical, L/W about 2.0; dorsally directed seta inserted at midlength; anterior third of lateral surface of ramus with seta and setule; posterior third with seta and 2 spinules; distal margin with 3 lateral and 3 medioventral spinules. Lengths of terminal caudal setae of holotype (in $\mathrm{mm}$ ), from lateral to medial: $0.12,0.67,0.04$. Seminal receptacle as in Fig. $7 \mathrm{~b}$; copulatory pore located at midlength of genital double-somite; spermatophore attached with abundant colored cement.

A1 8-segmented, setation same as that of previous species, aesthetasc on segment 4 reaching distal end of segment 7. Exopod of A2 (Fig. 7e) 2-segmented, exp1 with seta and fine spinules on distal margin, exp2 with 3 setae. Md palp as in Fig. 5 f. Other mouthparts typical for genus.

Setation formula of P1-4 typical for genus. P1 enpl shorter than exopod (Fig. 7f). Coxae of P1-4 with rows of microspinules (Fig. $7 \mathrm{f}-\mathrm{i}$ ). Couplers of P1-2 with row of spinules on each side.

P5 (Fig. 7j) with medial expansion of baseoendopod bearing 6 spines, second outermost one being short; exopod bearing 5 spines and several medial spinules, medial spine rudimentary, $\mathrm{L} / \mathrm{W}$ about 2.0 .

P6 (Fig. 7b) consisting of thin plate bearing 1 plumose seta.

Male: B.L. of 4 paratypes $0.82-0.92 \mathrm{~mm}$, and resembling female. Anal operculum with 12-16 spinules.

Al geniculate, 10-segmented, and armed as shown in Fig. 8a; aesthetasc on segment 5 reaching middle of 10 th segment.

P1 as in female; P2 endopod 2-segmented and as shown in fig. 8b; P3 enpl without medial seta; enp2 with medial process reaching tip of exp2; enp3 short, conical, with 2 spinules (Fig. 8c); P4 endopod deformed (Fig. 8d); P5 (Fig. 8e) with medial expansion of baseoendopod bearing 2 spines, exopod bearing 1 medial seta and 5 spines, medial seta on left side much longer than that on right.

Etymology. The species is named after the locality where it was first collected. 


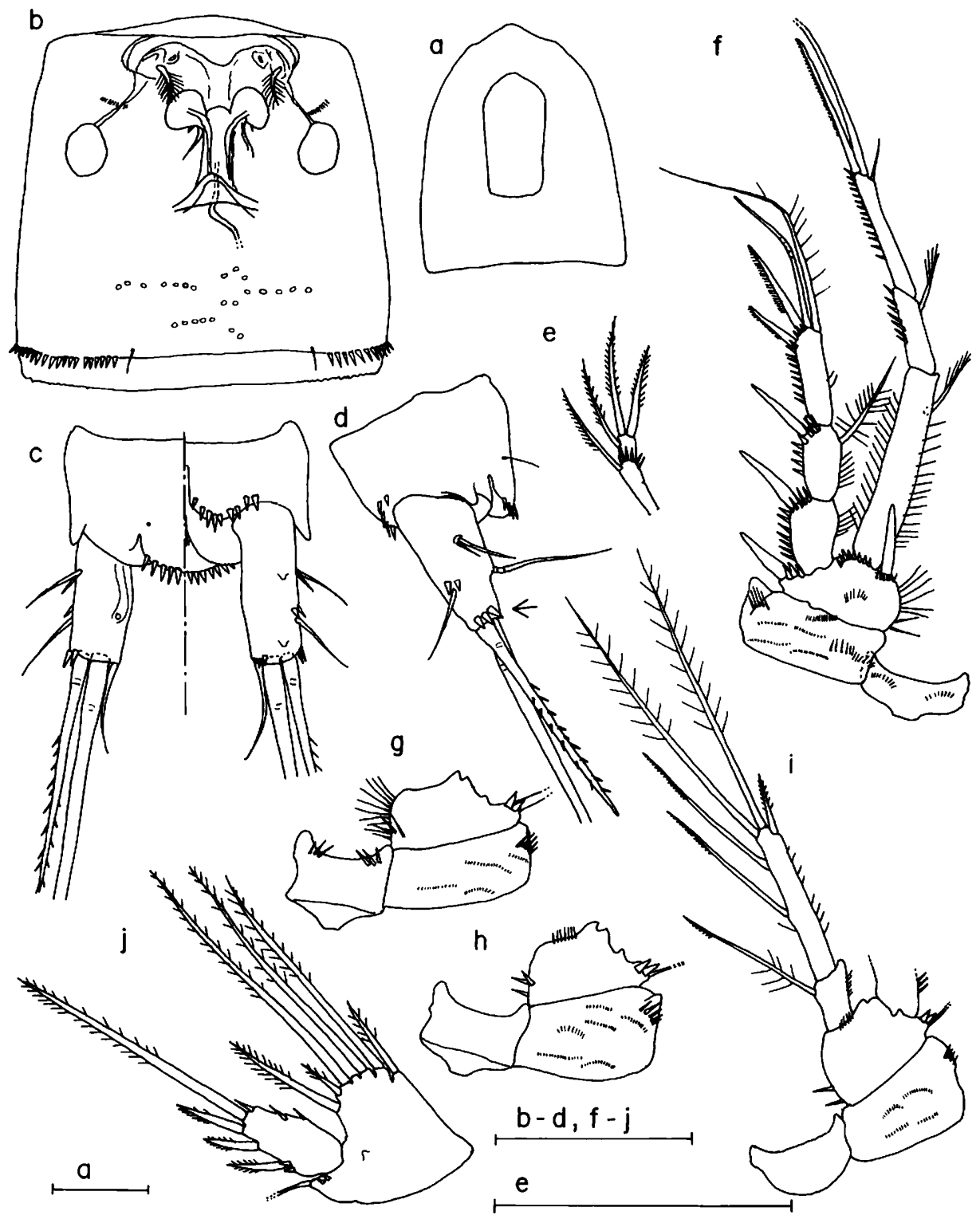

Fig. 7. Canthocamptus takkobuensis sp. nov., female, holotype: a, cephalothorax, dorsal; b, genital double-somite, ventral; c-d, anal somite and caudal ramus, dorsal/ventral and lateral; e, A2 exopod; f, P1 and coupler, anterior; $g$-h, P2-3 coxa, basis, and coupler, anterior; i, P4 endopod and coupler, anterior; j, P5. Scales $=100 \mu \mathrm{m}$.

Geographical distribution. Known from Lake Takkobu-numa, eastern Hokkaido, and a pond in Yoichi-machi, western Hokkaido. Further sampling from Hokkaido in early winter and the snowmelt season should yield more data on its occurrence. 


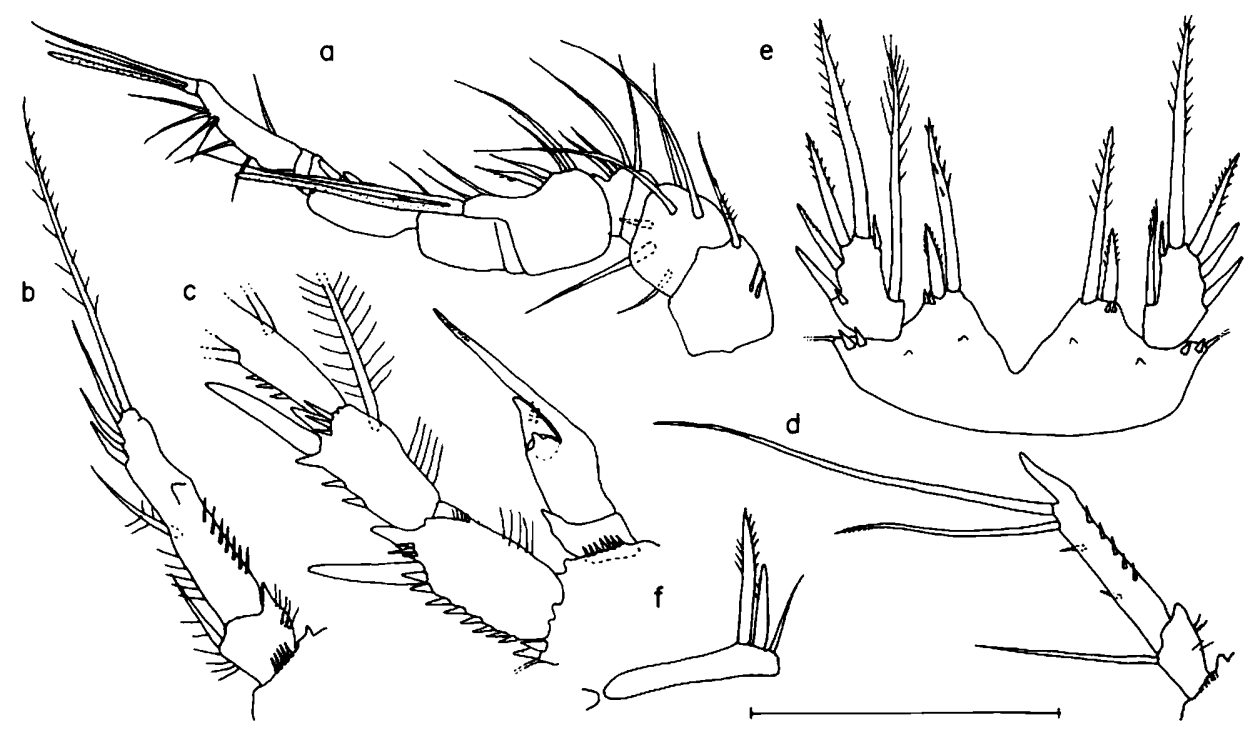

Fig. 8. Canthocamptus takkobuensis sp. nov., male, paratype: a, A1; b, P2 endopod; c, P3, anterior; d, P4 endopod; e, P5; f, P6. Scale $=100 \mu \mathrm{m}$.

Range of habitats. Lake Takkobu-numa is a swampy shallow lake. The pond in Yoichimachi is also shallow, and the bottom is covered by leaf litter.

Variation. No particular variation was seen in the two populations.

Affinities. The species is similar to $C$. macrosetifer, however, it differs in lacking spinules on the distal dorsal margin of the caudal rami (arrow in Fig. 7d), and in the number of spinules on the anal operculum (11-14 in C. takkobuensis, versus 6-9 in $C$. macrosetifer).

Key to the Four Japanese Species of Canthocamptus, Excluding the mirabilis -Group (For the mirabills-group, see Kikuchi and Ishida 1994)

\section{Females and males:}

1. Distal lateral corner of anal somite with protuberance (arrow in Fig. 5d) ….... 2

-. Distal lateral corner of anal somite with row of spinules (arrow in Fig. 1c) ….. 3

2. Distal edge of caudal rami with dorsal spinules (double arrow in Fig. 5d) …..... macrosetifer Ishida, sp. nov.

-. Distal edge of caudal rami without dorsal spinules (arrow in Fig. 7d)

takkobuensis Ishida, sp. nov.

3. Caudal rami without medial spinules (double arrow in Fig. 1d)

-. Caudal rami with medial spinules (arrow in Fig. 3c)

iaponicus Brehm, 1927

kitaurensis Kikuchi, sp. nov. 


\section{Acknowledgements}

We are grateful to Dr. A. Ohtaka of Hirosaki University, who collected specimens of C. iaponicus from the profundal bottom of Lake Biwa. Drs. M. Noda of the National Fisheries University, S. Ohtsuka of Hiroshima University, and S. Uchida of the Lake Biwa Museum provided field assistance. Dr. J. Sarvala, University of Turku, gave us valuable information on European Canthocamptus species. Sincere thanks are also due to Dr. J. W. Reid, National Museum of Natural History, Smithsonian Institution, for reading the manuscript, providing literature, and kindly lending specimens of $C$. staphylinoides. Dr. Ju-Shey Ho and an anoymous reviewer provided helpful comments.

\section{References}

Borutskii, E. V. 1952. Freshwater Harpacticoida. Fauna of USSR., Crustacea III(4). Academy of Sciences, Moscow, 425pp. [In Russian] (English translation: Israel Program for Scientific Translations. Jerusalem, 1964)

Brehm, V. 1927. Ueber die Tiefenfauna japanischer Seen. Archiv für Ilydrobiologie 18: 135-150.

Dussart, B. 1967. Les Copepodes des Eaux Continentales. Tome I: Calanoides et Harpacticoïdes. Editions N. Boubée \& Cie, Paris, 500pp.

Gurney, R. 1932. British Freshwater Copepoda. Vol. 2 (Harpacticoida). Ray Society, London, $336 \mathrm{pp}$.

Ishida, T. 1987. Freshwater harpacticoid copepods of Hokkaido, northern Japan. Scientific Report of Hokkaido Salmon Hatchery 41:77-118.

Ishida, T. 1989. Copepods in the mountain waters of Honshu, Japan. Scientific Report of Hokkaido Salmon Hatchery 43: 1-21.

Ishida, T. 1990. Copepods in the mountain waters of Kyushu, Tsushima and Ryukyu Islands, southwestern Japan. Scientific Report of Hokkaido Salmon Hatchery 44: 39-51.

Ishida, T. 1995. Copepods in the floodplain waters of Japan. I. Shiribetsu River basin, Hokkaido, northern Japan. Japanese Journal of Limnology 56(4): 297-302. [In Japanese, with English summary]

Itô, T. and Y. Miura 1973. Copepoda. Pp. 434-453. In: Ueno, M. (Ed.) Kawamura's Japanese Freshwater Biology. Zukan no I Iokuryukan, Tokyo, 720pp. [In Japanese]

Itô, T. and T. Takashio 1980. Canthocamptus mirabilis Štěrba (Copepoda, Harpacticoida) from Hokkaido, northern Japan. Annotationes Zoologicae Japonenses 53(3): 210-219.

Kikuchi, Y. and T.Ishida 1994. A species group of genus Canthocamptus (Copepoda: Harpacticoida) in Japan, including descriptions of four new species. Bulletin of the Biogeographical Society of Japan 49: 37-46.

Lang, K. 1948. Monographie der Harpacticiden. Vols I, II, Nordiska Bokhandeln, Stockholm, $1648 \mathrm{pp}$.

Pearse, A. S. 1905. Contributions to the copepod fauna of Nebraska and other states. Proceedings of the American Microscopical Society 26: 145-160.

Tai, A. and Y. Song 1979. Harpacticoida Sars, 1903. Pp.164-300. In: Fauna Editorial Committee, Academia Sinica (Ed.) Fauna Sinica Cruslacea Freshwater Copepods. Science Press, Peking, 450pp. [In Chinese] 